Article

\title{
Exploring the Relationship between Communication and Success of Construction Projects: The Mediating Role of Conflict
}

\author{
Summaira Malik $^{1, *}$, Muhammad Taqi ${ }^{2}$, José Moleiro Martins ${ }^{3,4}\left(\mathbb{D}\right.$, Mário Nuno Mata ${ }^{3}$ (D) João Manuel Pereira ${ }^{3}(\mathbb{D}$ \\ and António Abreu 5,6
}

check for

updates

Citation: Malik, S.; Taqi, M.;

Martins, J.M.; Mata, M.N.;

Pereira, J.M.; Abreu, A. Exploring the

Relationship between

Communication and Success of Construction Projects: The Mediating Role of Conflict. Sustainability 2021,

13, 4513. https://doi.org/10.3390/ su13084513

Academic Editor: Ralph Hansmann

Received: 12 March 2021

Accepted: 8 April 2021

Published: 19 April 2021

Publisher's Note: MDPI stays neutral with regard to jurisdictional claims in published maps and institutional affiliations.

Copyright: (c) 2021 by the authors. Licensee MDPI, Basel, Switzerland. This article is an open access article distributed under the terms and conditions of the Creative Commons Attribution (CC BY) license (https:/ / creativecommons.org/licenses/by/ $4.0 /)$.
1 Department of Economics, Lahore Campus, COMSATS University Islamabad (CUI), Defence Road, Off Raiwind Road, Lahore 54000, Pakistan

2 Department of Management Science, Lahore Campus, COMSATS University Islamabad (CUI), Defence Road, Off Raiwind Road, Lahore 54000, Pakistan; taqiali02@gmail.com

3 ISCAL (Instituto Superior de Contabilidade e Administração de Lisboa), Instituto Politécnico de Lisboa, Avenida Miguel Bombarda, 20, 1069-035 Lisboa, Portugal; zdmmartins@gmail.com (J.M.M.); mnmata@iscal.ipl.pt (M.N.M.); jmfpereira@iscal.ipl.pt (J.M.P.)

4 Instituto Universitário de Lisboa (ISCTE-IUL), Business Research Unit (BRU-IUL), 1069-035 Lisboa, Portugal

5 Department of Mechanical Engineering, Polytechnic Institute of Lisbon, 1959-007 Lisbon, Portugal; ajfa@dem.isel.ipl.pt

6 CTS Uninova, Faculdade de Ciências e Tecnologia, Universidade Nova de Lisboa, 2829-516 Caparica, Portugal

* Correspondence: drsummairamalik@cuilahore.edu.pk

\begin{abstract}
The success of a construction project is a widely discussed topic, even today, and there exists a difference of opinion. The impact of communication and conflict on project success is an important, but least addressed, issue in literature, especially in the case of underdeveloped countries. Miscommunication and conflict not only hinder the success of a project but also may lead to conflicts. The focus of this paper was to examine the impact of communication on project success with the mediating role of conflict. By using SPSS, demographics, descriptive statistics and correlation were determined. Smart PLS version 3.0 was used for confirmatory factor analysis (CFA), internal accuracy and validity estimates, hypothesis checking and mediation testing. The results showed that formal communication has a negative impact on the success of a construction project, resulting in conflicts among project team members, whereas informal communication and communication willingness have a positive impact on project success because people tend to know each other, and trust is developed. Task, process and relationship conflicts were used as mediating variables. It was found that task conflict effects the relations positively because project team members suggest different ways to do a certain task, and, hence, project success is achieved. On the contrary, process conflict and relationship conflict have a negative impact on communication and project success. Both of these conflicts lead to miscommunication, and project success is compromised. Hence, it is the responsibility of the project manager to enhance communication among project team members and to reduce the detrimental effects of process and relationship conflict on project success.
\end{abstract}

Keywords: communication; formal communication; informal communication; communication willingness; conflict; project manager

\section{Introduction}

The construction industry plays a vital role in the development of the country. It has the potential to boost the economy of the country and creates employment opportunities as well [1]. It uses laborers and skilled professionals to deliver a project within the specified time and within the budget allocated to satisfy the client or customer [2].

The construction industry is purely a project-based industry and a project is temporary in nature [3]. A construction firm can get the competitive edge based on in its 
performance in the market [4]. The three major participants are Client (Owner), Contractor and the Consultant, and the relationship among them is temporary and fragile [5]. A construction project, therefore, involves teams of the Client, Contractor and the Consultants. Construction project teams communicate to exchange information from each other [6]. The information could be financial or technical. Changes to drawings, specifications, and design and progress status are the key elements to communicate among project teams [7]. Effective communication is needed to deliver a project on time. On the other hand, miscommunication leads to failure in achieving objectives of a project [8]. The project teams work with each other and they depend on each other, which may lead to conflicts [9]. Conflicts in projects make it difficult to achieve project objectives and may lead to failure [10]. Conflicts arise in projects over resources, duties, tasks, work hours, incentives, etc. It is the responsibility of project manager to resolve the conflict without any time delays to prevent the project failure. Success of a construction project is a widely discussed topic, even today, and there exists a difference of opinion in this regard. Since, the inception of project management, the success of the project is measured by the iron triangle, i.e., cost, time, scope and quality [11]. A construction project is successful if it is constructed and operated successfully [12]. A project, if successful, causes satisfaction of the client [13].

In the literature, proper communication and co-ordination have been identified as a key factor in success of a project. In [14,15], it was found that conflict has an inverse relation with project success. It is also evident from the literature that project success and sustainability seem to fluctuate in the same manner, and there are no significant discrepancies between them [16,17]. The relationship between different levels of integration of sustainability and project success is not a simple one. The literature identified nine dimensions of sustainability and six measures of project success [18]. Another study by [19] found cases where successful projects were induced by sustainability and also where a sustainable practice did not lead to success. They concluded that there should be other factors influencing a project's outcome. According to [20], project success is linked to the project manager's ethics in business. In fact, the International Project Management Association code explicitly mentions sustainability as one of the professional responsibilities of the project manager, without explicitly linking this to project success.

The existing literature is extensive with regard to communication types, conflict types and project success, but is limited in studying the relationship between them, especially in the case of the construction industry. Secondly, the norms, culture, diversity and operating procedures affect the governing rules and regulations of the construction industry of any country, so the impact could be case specific. Hence, it is important to investigate them and formulate a better policy for practitioners in the construction industry. The above section presented a brief introduction of the problem; in Section 2, an in-depth review of previous and relevant research works on team communication, team conflict and project success, along with some contradictions and gaps in previous research are discussed. Section 3 presents a research framework of the study. In Section 4, empirical findings are discussed. The discussion on results is presented in Section 5. The conclusion and the managerial implications, along with limitations and future recommendations, are discussed in Section 6.

\section{Literature Review}

\subsection{Team Communication}

The transfer of information from one person to another is referred to as communication [21]. Ref. [22] has argued that an interactive platform for stakeholders may be required to overcome communication difficulties. According to [23], effective communication is very important and fundamental in project management since teams work together to achieve project goals. Construction teams need to have good communication strategies because of the temporary and fragmented nature of the construction industry [24]. Ref. [6] has divided communication into formal and informal communication. Both of these are necessary to make a project successful. According to [25], willingness to communicate with 
the team is another dimension of communication that needs to be studied. This study has taken three dimensions of communication, i.e., formal and informal communication and communication willingness.

\subsection{Team Conflict}

A disease that arises because of differences in goals and interest is conflict [26]. According to [27], conflict arises because of differences in opinion, ideas, beliefs and interest of people involved in a project. A conflict can have a positive impact on an organization's business, e.g., increasing productivity and exploring better solutions, but at the same time, a conflict can have a negative impact as well, such as poor communication and employees not willing to co-operate with each other [28]. Present-day projects need multiple organizations to work together to accomplish project tasks, therefore, making the teams more prone to develop conflict among them [29]. In the projects of the modern era, the possibility of conflicts in projects is increased because of the diversified background of individuals within teams [30]. According to [31], conflict is of two types, namely, task oriented and relationship oriented. However, there is another type of conflict referred to as process conflict [32]. In this paper, conflict among people involved in the project was divided into three types as task, process and relationship conflict.

\subsection{Project Success}

Project success has become vitally important in the field of project management. It has been discussed widely since the inception of this field. Project success has attracted many authors $[33,34]$. Many authors have come up with different factors that are critical to ensuring a project as successful [35]. Ref. [36] examined the critical success factors (CSFs) for construction and PPP projects, respectively, have been identified. To understand project success, some authors have emphasized the consideration of perspectives. In the short term, project success could be measure by the iron triangle, but in the long term, customer satisfaction and successful operations of building or facility also come under the definition of project success $[13,37]$.

\subsection{Impact of Team Communication on Project Success}

Team communication is discussed broadly in the literature as it plays an important role in the success and goal accomplishment of a project [38]. With the evolution of time, project success has become more difficult, and the impact of communication on project success demands attention [39]. According to [38], team communication management is of great importance in the field of project management. The authors of $[40,41]$ have also put great emphasis on communication among individuals and teams, since it significantly affects the project.

There are three dimensions used in the literature to measure communication, i.e., formal communication, informal communication and willingness to communicate [42-44]. Formal communication includes meetings, document sharing, etc., and barriers among team members are not removed by this form of communication [44,45]. On the other hand, by the help of informal communication, people tend to know each other's culture, habits, and skills, therefore, conflicts are resolved, and project success is achieved [46]. According to $[47,48]$, willingness to communicate increases information sharing among teams and, hence, facilitates project success. This study hypothesized that:

Hypothesis $\mathbf{1}$ (H1). There exists a relationship between formal communication and project success.

Hypothesis 2 (H2). There exists a relationship between informal communication and project success.

Hypothesis $3(\mathbf{H} 3)$. There exists a relationship between communication willingness and project success. 


\subsection{Communication Conflict Interaction and Its Impact on Project Success}

The construction industry plays a vital role in the economy of any country and is a project-based industry [49]. Due to large-scale projects, multiple teams and reduced profits, conflicts continue to arise [50]. According to [51], conflicts must be avoided to the maximum extent because of their devastating nature. Conflict is a serious difference of opinions among individuals or teams and can lead to cost overruns, time delays and damage to an organization's business and, hence, may lead to underperformance of a construction project [52]. According to [5], lack of communication is one of the reasons that can contribute to conflicts arising. Communication problems do occur on site, and these must be solved timely and on the spot (if possible) to prevent poor relation conflicts among individuals [51]. For project success, many critical success factors have been identified by authors since the inception of this field. [53], argued that conflict leads to failure of a project and management of conflict is important in determining the fate of a project. Communication difficulties are devastating for the project goals and can lead to conflict, which ultimately leads to failure of the project [54].

From the literature, it is evident that both communication and conflict do affect the project success.

According to [55], task conflict has a positive impact on project success. The study tests the following hypotheses:

Hypothesis $\mathbf{H 4}$ (H4a). The relationship between formal communication and project success is mediated by task conflict.

Hypothesis $\mathbf{H 4} \mathbf{( H 4 b )}$. The relationship between informal communication and project success is mediated by task conflict.

Hypothesis $\mathbf{H} 4 \mathbf{( H 4 c )}$. The relationship between communication willingness and project success is mediated by task conflict.

When members of a project team have disagreements among each other regarding the procedure or processes involved in the project, process conflict arises [56]. According to [55], process conflict is positively influenced by informal communication and communication willingness but is negatively related to formal communication. Process conflict has a negative impact on project success [55]. The study empirically tests the following hypotheses:

Hypothesis $\mathbf{H} 5$ (H5a). The relationship between formal communication and project success is mediated by process conflict.

Hypothesis $\mathbf{H} \mathbf{5} \mathbf{( H 5 b )}$. The relationship between informal communication and project success is mediated by process conflict.

Hypothesis $\mathbf{H} 5$ (H5c). The relationship between communication willingness and project success is mediated by process conflict.

The negative emotions or feelings of one team member for another can lead to relationship conflict among them [57]. According to [58], relationship conflict has a negative impact on project success. According to [59], relationship conflict is positively related to formal communication but negatively related to informal communication and communication willingness. This study hypothesized that;

Hypothesis $\mathbf{H 6}$ (H6a). The relationship between formal communication and project success is mediated by relationship conflict. 
Hypothesis $\mathbf{H 6}$ (H6b). The relationship between informal communication and project success is mediated by relationship conflict.

Hypothesis $\mathbf{H 6}$ (H6c). The relationship between communication willingness and project success is mediated by relationship conflict.

\section{Research Methodology}

\subsection{Research Framework}

The success of a construction project is dependent on many factors and is discussed widely. While executing a project, different people work together in teams and communicate with each other leading the project to its pre-determined objectives. However, miscommunication leads to conflicts, which, if not resolved timely and properly, can lead a project to a partial or complete failure.

Hence, there is a need to study the relationship of communication types with project success and also to study the mediating effect of different types of conflicts on this relationship [59].

Our theoretical model is based on the research work of Wu et al. [59]. The items to measure the dimensions of communication were taken from the research work of [43,45], whereas the items to measure types of conflict were taken from the research work of [59]. Project success was measured with the help of items used by [60]. The research framework is shown in Figure 1.

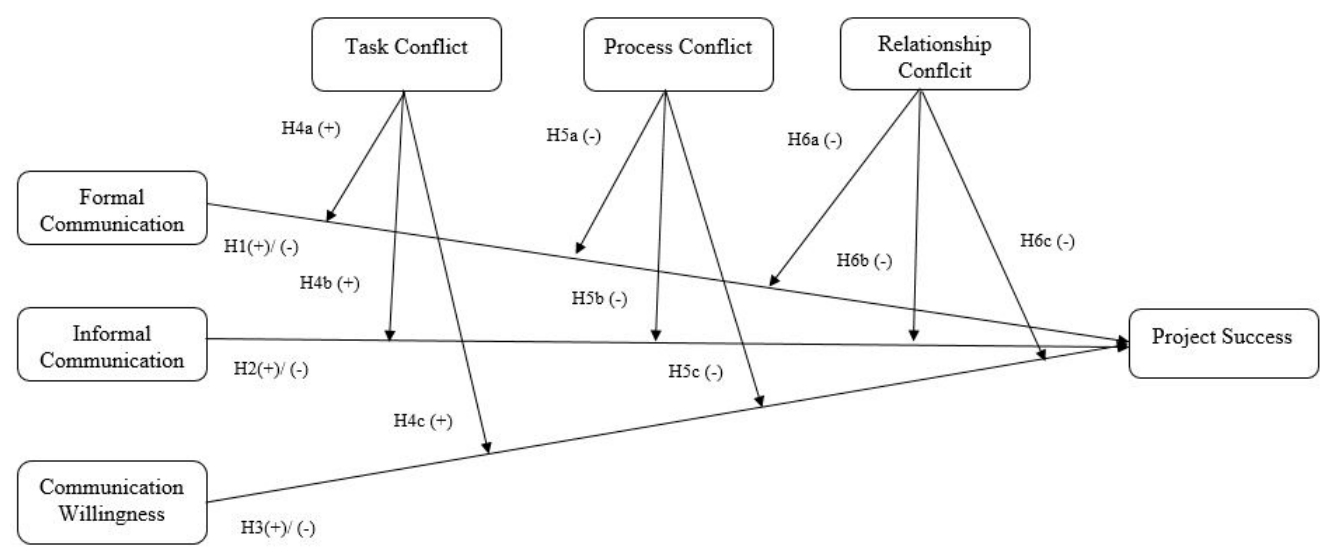

Figure 1. Research framework showing direct relation of communication types with project success and mediating role of conflict types.

\subsection{Population and Sampling}

The target population was large- and medium-sized construction firms based in Lahore, and our respondents were professionals (top and middle management) working in these firms. The reason for choosing Lahore city was that Lahore is the second largest metropolitan city of Pakistan. It is also the capital city of Punjab province [61]. Lahore city is the main hub for construction firms. Most of the projects are initiated from this city and are then executed in different cities. The professionals perform their duties at the construction site(s) and also pay visits to their offices for meetings and other official engagements. A list of construction companies was acquired from the website of the Pakistan Engineering Council (PEC), which is a body established under the Constitution of Pakistan to regulate the engineering profession in Pakistan. At least two professionals from a firm were approached to avoid single source bias.

Cochran's formula was used to evaluate the sample size. It is used when target population size is unknown or infinite [62]. A total of 385 questionnaires were distributed, and 267 valid responses were received from twenty-seven companies. When dealing with average sample sizes, the technique of Structural Equation Modeling (SEM) was used. 
According to [63], this technique gives the best results when the sample size is small. For testing of the hypotheses and mediation analysis, Smart PLS software was used. Smart PLS is accepted as the most comprehensive software by the research community, especially when SEM technique is employed [64].

\section{Results}

\subsection{Demographic Analysis}

For the computation of demographics and reliability, Statistical Package for Social Sciences (SPSS) version 21 was used. The demographic calculations are shown below in Table 1.

Table 1. The demographic analysis of respondents.

\begin{tabular}{|c|c|c|}
\hline Respondent Designation & Frequency & Percent \\
\hline Planning Engineer & 68 & 25.5 \\
\hline Project Engineer & 64 & 24.0 \\
\hline Project Manager & 45 & 16.9 \\
\hline Senior Engineer & 71 & 26.6 \\
\hline Chief Executive & 6 & 2.2 \\
\hline Managing Director & 13 & 4.9 \\
\hline \multicolumn{3}{|l|}{ Experience in Years } \\
\hline$<5$ Years & 29 & 10.9 \\
\hline 5-10 Years & 55 & 20.6 \\
\hline 10-15 Years & 123 & 46.1 \\
\hline 15-20 Years & 26 & 9.7 \\
\hline$>20$ Years & 34 & 12.7 \\
\hline \multicolumn{3}{|l|}{$\begin{array}{c}\text { Cost of Last Completed } \\
\text { Project }\end{array}$} \\
\hline$<$ PKR $50 \mathrm{M}$ & 47 & 17.6 \\
\hline PKR 50-100 M & 82 & 30.7 \\
\hline PKR 100-250 M & 47 & 17.6 \\
\hline PKR 250-450 M & 60 & 22.5 \\
\hline$>$ PKR $450 \mathrm{M}$ & 31 & 11.6 \\
\hline Total & 267 & 100 \\
\hline
\end{tabular}

Planning engineers who gave responses were 68 in number, constituting a percentage of $25.5 \%$; project engineers were 64 , with a percentage of $24 \%$; project managers were 45 , with a percentage of $16.9 \%$; senior managers were 71 , with a percentage of $26.6 \%$. Similarly, chief executives and managing directors were 6 and 13 in number, with percentages of $2.2 \%$ and $4.9 \%$, respectively. Experience is a critical factor when someone is asked to give a response, as experience is linked to more exposure to the problems being faced. The respondents with experience less than five years were 29 , from five to ten years were 55 , from ten to fifteen years were 123 , from fifteen to twenty years were 26 , and above twenty years were 34 in number.

Respondents were asked to write the cost of their last completed projects. The respondents from large organizations completed their last project with a much higher cost. The projects with cost less than fifty million were 47 , from fifty to one hundred million were 82 , from one hundred to two hundred and fifty million were 47 , from two hundred and fifty to four hundred and fifty were 60, and above four hundred and fifty were 31 in number. 


\subsection{Reliability}

To calculate internal consistency, the Cronbach alpha was used. A value greater than 0.7 indicates good constructs [65]. The values are shown in Table 2 below.

Table 2. Reliability of variables.

\begin{tabular}{cccc}
\hline Variable Description & Coded Name & Number of Items & Cronbach's Alpha Value \\
\hline $\begin{array}{c}\text { Formal } \\
\text { Communication }\end{array}$ & FC & 7 & 0.92 \\
\hline $\begin{array}{c}\text { Informal } \\
\text { Communication }\end{array}$ & IC & 6 & 0.799 \\
\hline $\begin{array}{c}\text { Communication } \\
\text { Willingness }\end{array}$ & CW & 6 & 0.75 \\
\hline Task Conflict & TC & 7 & 0.775 \\
\hline Process Conflict & PC & 6 & 0.814 \\
\hline Relationship Conflict & RC & 7 & 0.883 \\
\hline Project Success & PS & 11 & 0.916 \\
\hline
\end{tabular}

\subsection{Confirmatory Factor Analysis (CFA)}

CFA is a theory-driven approach to empirically test the established theory with the help of a questionnaire. SmartPLS (version 3.0) software was used for CFA.

Table 3 below shows the loading (direct) scores. The loading scores of indicators that represent a construct must be greater than the values in other rows under different constructs.

Table 3. Direct loading scores.

\begin{tabular}{|c|c|c|c|c|c|c|c|}
\hline & $\mathrm{CW}$ & FC & IC & PC & PS & RC & TC \\
\hline CW1 & 0.844 & & & & & & \\
\hline CW2 & 0.843 & & & & & & \\
\hline CW4 & 0.548 & & & & & & \\
\hline CW5 & 0.782 & & & & & & \\
\hline FC1 & & 0.834 & & & & & \\
\hline FC2 & & 0.821 & & & & & \\
\hline FC3 & & 0.814 & & & & & \\
\hline FC4 & & 0.798 & & & & & \\
\hline FC5 & & 0.854 & & & & & \\
\hline FC6 & & 0.819 & & & & & \\
\hline FC7 & & 0.808 & & & & & \\
\hline IC1 & & & 0.74 & & & & \\
\hline IC2 & & & 0.764 & & & & \\
\hline IC3 & & & 0.823 & & & & \\
\hline IC4 & & & 0.831 & & & & \\
\hline IC5 & & & 0.786 & & & & \\
\hline IC6 & & & 0.913 & & & & \\
\hline
\end{tabular}


Table 3. Cont.

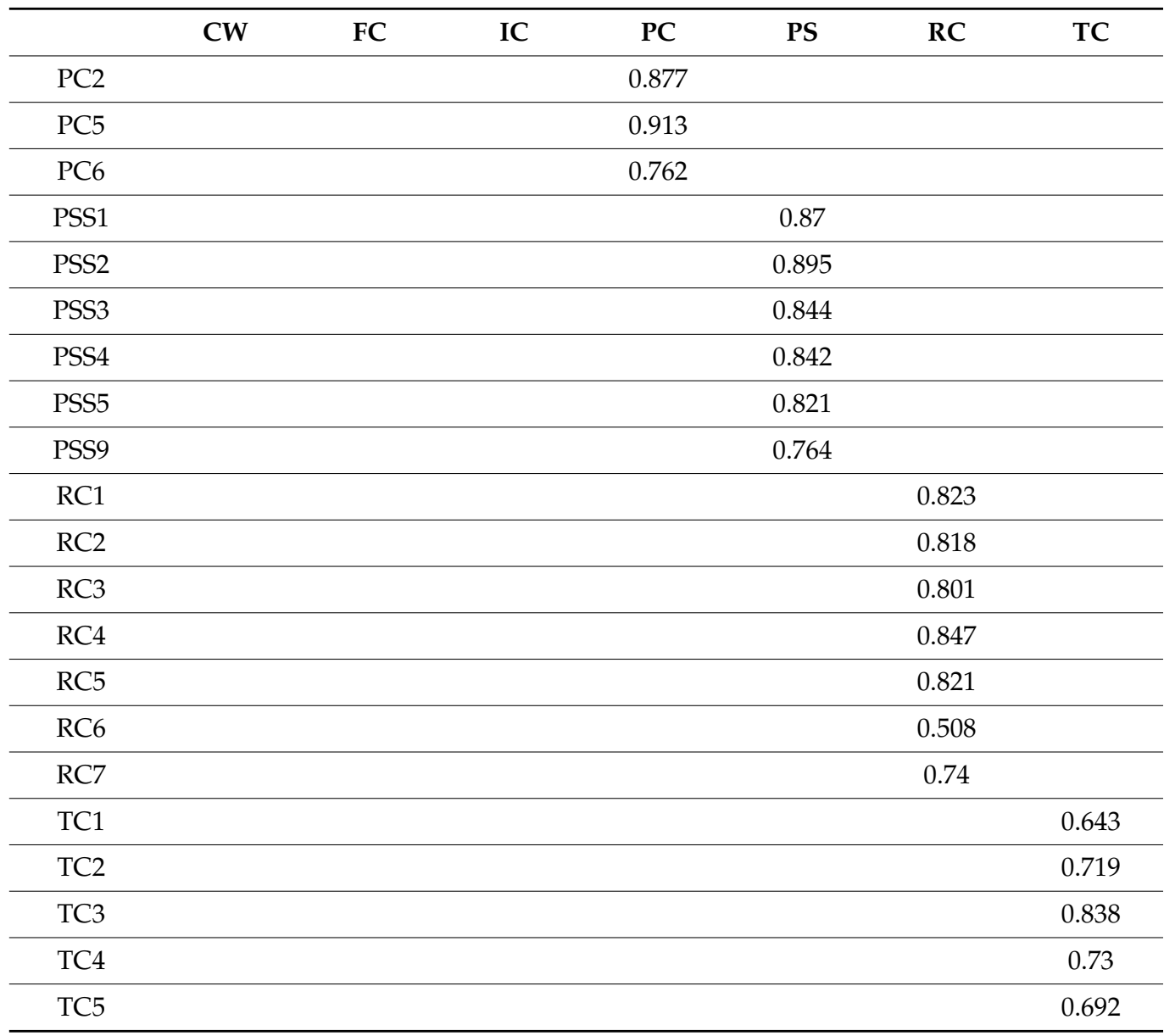

Secondly, an indicator is retained if its direct loading score is greater than 0.7 [66]. According to [67], there is maximum allowance of $30 \%$ reduction in indicators. The number of items in the questionnaire was previously 50, but 12 were discarded, whereas the maximum allowed was 15 in our case. The discarded items were CW3, CW6, PC1, PC3, PC4, PSS6, PSS7, PSS8, PSS10, PSS11, TC6 and TC7.

The loading scores are also presented in Figure 2.

\subsection{Discriminant Validity}

The following Table 4 represents the results of the Fornell and Larcker criterion. The values in diagonal are bolded and they represent the values of the square root of average variance extracted (AVE). If the bold values are greater than the other in the same column, then the discriminant validity is established.

\subsection{Testing of Hypotheses}

For the testing of the hypotheses, Smart PLS (version 3.0) was used.

\subsubsection{Direct Relations}

Communication was divided into three dimensions, namely, as formal communication, informal communication and communication willingness. The first three hypotheses were concerned about the impact of communication on project success. The findings are stated in Table 5. 
Table 4. Discriminant validity by Fornell and Larcker criterion.

\begin{tabular}{cccccccc}
\hline & CW & FC & IC & PC & PS & RC & TC \\
\hline CW & $\mathbf{0 . 7 6 4}$ & & & & & & \\
\hline FC & 0.102 & $\mathbf{0 . 8 2 1}$ & & & & & \\
\hline IC & 0.717 & 0.072 & $\mathbf{0 . 7 2 8}$ & & & & \\
\hline PC & 0.454 & 0.051 & 0.461 & $\mathbf{0 . 8 5 3}$ & & & \\
\hline PS & 0.106 & 0.667 & 0.069 & 0.045 & $\mathbf{0 . 8 4}$ & & \\
\hline RC & 0.116 & 0.696 & 0.082 & 0.095 & 0.692 & $\mathbf{0 . 7 7 3}$ & \\
\hline TC & 0.785 & 0.091 & 0.665 & 0.526 & 0.066 & 0.057 & $\mathbf{0 . 7 2 7}$ \\
\hline
\end{tabular}

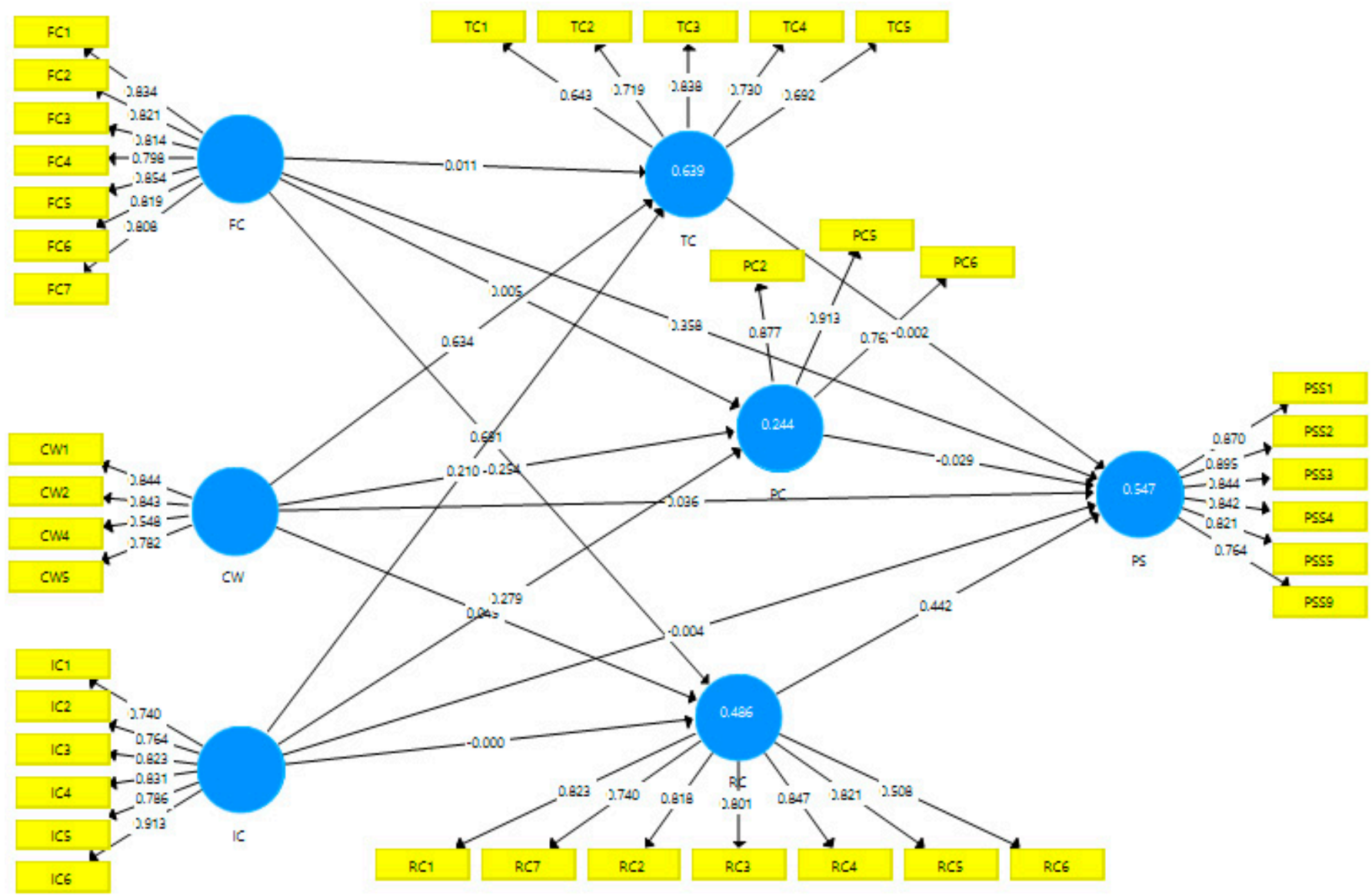

Figure 2. Confirmatory factor analysis.

Table 5. Results of Hypothesis 1 (H1), Hypothesis 2 (H2) and Hypothesis 3 (H3).

\begin{tabular}{ccccccc}
\hline Hypotheses & $\begin{array}{c}\text { Hypothesis } \\
\text { Direction }\end{array}$ & $\begin{array}{c}\text { Original } \\
\text { Sample (O) }\end{array}$ & $\begin{array}{c}\text { Standard Deviation } \\
\text { (STDEV) }\end{array}$ & $\begin{array}{c}\text { T Statistics } \\
\text { (IO/STDEVI) }\end{array}$ & Results & Impact \\
\hline H1 & FC -> PS & -0.358 & 0.078 & 4.597 & Supported & - ve \\
\hline H2 & IC -> PS & 0.361 & 0.062 & 5.822 & Supported & + ve \\
\hline H3 & CW -> PS & 0.158 & 0.08 & 1.975 & Supported \\
\hline
\end{tabular}


In Table 5, H1 states that here exists a relationship between formal communication and project success. The direction of the hypothesis was not mentioned in the hypothesis due to mixed evidence available in the literature. The results indicated a negative relationship and the hypothesis was accepted. $\mathrm{H} 2$ states that there exists a relationship between informal communication and project success. The hypothesis was validated, as the $t$ value is highly significant. H3 states that communication willingness impacts the project success, which was also validated, as the $t$ value in this case was 1.975, which is greater than 1.65. The hypothesis was accepted with positive impact.

\subsubsection{Indirect Relations}

Three mediators (task conflict, process conflict and relationship conflict) were used to check the indirect relationship. The results are presented below:

Task Conflict as a Mediator

The results of task conflict as a mediator are presented in Table 6 below.

Table 6. Task conflict as a mediator.

\begin{tabular}{cccc}
\hline & Original Sample (O) & Standard Deviation (STDEV) & T Statistics ( I O/STDEV I) \\
\hline Formal Communication & & & \\
\hline FC $->$ TC & -0.118 & 0.04 & 2.95 \\
\hline TC $->$ PS & 0.314 & 0.077 & 4.077 \\
\hline FC $>$ PS with TC as mediator & 0.321 & 0.07 & 4.58 \\
\hline Informal Communication & & & 3.517 \\
\hline IC $->$ TC & 0.21 & 0.06 & 4.077 \\
\hline TC $->$ PS & 0.314 & 0.077 & 7.42 \\
\hline IC $>$ PS with TC as mediator & 0.141 & 0.019 & 11.301 \\
\hline Communication Willingness & & & 4.077 \\
\hline CW $->$ TC & 0.634 & 0.056 & 2.982 \\
\hline TC $->$ PS & 0.314 & 0.077 & 0.056 \\
\hline CW $->$ PS with TC as mediator & 0.167 & & \\
\hline
\end{tabular}

In Table 6 , when the mediator was introduced in formal communication, $t=4.58$, the strength of the relationship increased with the mediator. The mediator played a significant role in the informal communication and communication willingness.

Process Conflict as a Mediator

The empirical findings of process conflict as a mediator are presented in Table 7 below.

The relationship of formal communication with process conflict and process conflict with project success was significant. However, the $t$ value was significant when the process conflict was introduced as a mediator. The hypothesis was accepted with negative impact of process conflict as a mediator.

\section{Relationship Conflict as a Mediator}

This paper hypothesized that the relationship between formal communication and project success is mediated by relationship conflict. Results are presented in the Table 8 . 
Table 7. Process conflict as a mediator.

\begin{tabular}{|c|c|c|c|}
\hline & Original Sample (O) & Standard Deviation (STDEV) & T Statistics (I O/STDEVI) \\
\hline \multicolumn{4}{|l|}{ Formal Communication } \\
\hline $\mathrm{FC} \rightarrow \mathrm{PC}$ & 0.0187 & 0.056 & 3.339 \\
\hline PC $->$ PS & -0.293 & 0.058 & 5.051 \\
\hline FC $->$ PS with PC as mediator & -0.419 & 0.093 & 4.505 \\
\hline \multicolumn{4}{|l|}{ Informal Communication } \\
\hline IC $\rightarrow$ PC & 0.279 & 0.082 & 3.396 \\
\hline PC $->$ PS & -0.293 & 0.058 & 5.051 \\
\hline IC $->$ PS with PC as mediator & -0.127 & 0.054 & 2.351 \\
\hline \multicolumn{4}{|l|}{ Communication Willingness } \\
\hline $\mathrm{CW}->\mathrm{PC}$ & 0.254 & 0.09 & 2.807 \\
\hline PC $->$ PS & -0.293 & 0.058 & 5.051 \\
\hline CW $->$ PS with PC as mediator & -0.289 & 0.071 & 4.07 \\
\hline
\end{tabular}

Table 8. Relationship conflict as a mediator.

\begin{tabular}{|c|c|c|c|}
\hline & Original Sample (O) & Standard Deviation (STDEV) & T Statistics ( $|\mathrm{O} / \mathrm{STDEV}|)$ \\
\hline \multicolumn{4}{|l|}{ Formal Communication } \\
\hline $\mathrm{FC}->\mathrm{RC}$ & 0.691 & 0.041 & 17.068 \\
\hline $\mathrm{RC}->\mathrm{PS}$ & -0.442 & 0.072 & 6.109 \\
\hline FC $->$ PS with RC as mediator & -0.302 & 0.05 & 6.074 \\
\hline \multicolumn{4}{|l|}{ Informal Communication } \\
\hline IC $\rightarrow$ RC & 0.616 & 0.074 & 8.324 \\
\hline $\mathrm{RC}->\mathrm{PS}$ & -0.442 & 0.072 & 6.109 \\
\hline IC -> PS with RC as mediator & -0.244 & 0.032 & 7.62 \\
\hline \multicolumn{4}{|l|}{ Communication Willingness } \\
\hline $\mathrm{CW}->\mathrm{RC}$ & 0.245 & 0.069 & 3.55 \\
\hline RC $->$ PS & -0.442 & 0.072 & 6.109 \\
\hline $\begin{array}{c}\mathrm{CW}->\text { PS with RC as } \\
\text { mediator }\end{array}$ & -0.05 & 0.027 & 1.85 \\
\hline
\end{tabular}

The addition of relationship communication as a mediator between formal communication and project success was statistically significant, hence, the hypothesis was accepted. However, the impact was negative.

When relationship conflict was introduced as a mediating variable in communication willingness and project success, the $t$ value was relatively lesser, i.e., 1.85, but greater than 1.65 , hence, the hypothesis was accepted with positive impact.

\section{Discussion}

Construction projects are increasing day by day. Their complexity is also increasing, hence, demanding more expertise and more involvement of people. The developing countries are faced with the problems of lack of facilities such as educational institutes, hospitals, high rise buildings, etc., so construction work is always in continuation. Communication among people is very important and plays an important role in project completion and success. People with different backgrounds, culture, norms and behaviors, interact with each other and, hence, conflict arises. This research was focused on answering the two 
questions: first, to check and analyze the impact of communication on project success; second, to check the mediating role of conflict on the relationship between communication and project success.

Communication in this paper was divided into three dimensions, i.e., formal communication, informal communication and communication willingness. People involved in projects communicate in different ways. When they communicate through meetings, in office discussions, emails, etc., they communicate formally. When people communicate with each other exchanging information about each other's background, habits, family, etc., this is referred to as informal communication. According to [43], communication willingness is basically the will to talk to each other that helps in the sharing of critical data among them and is an important factor that leads to enhanced coordination and trust. The first three hypotheses were concerned about the relationship between communication and project success. The relationship of formal communication with project success was found statistically significant, but the impact was negative (H1). It was because of the reason that, although formal communication enhances coordination among teams or people, it does not help them in developing trust mechanisms and, as a result, the desired project success is not achieved, and differences between them are not resolved by this form of communication $[44,45]$.

Informal communication was also found to be statistically significant and positively affecting project success $(\mathrm{H} 2)$. When people communicate informally, they tend to know more about each other, including about the other's culture, background, skills, etc., and so conflicts and differences are more likely to be resolved, and project success is achieved, which is also supported by some previous research [46].

The relationship of communication willingness and project success was also statistically significant and positive (H3). The will to communicate eases the way of information sharing between people, differences are more readily resolved and, as a result, project success is facilitated $[48,59]$.

When task conflict was introduced as a mediator between the formal communication and project success, the results were significant. A positive impact was observed, but the mediation was observed to be partial (H4a). The reason is, in task-oriented conflict, people in teams argue and agree or disagree with each other in the ways to accomplish a certain task, which results in an increase in productivity, and project success is achieved. The effect of formal communication is negative on project success, but this effect is lessened by task conflict [68].

Similarly, when task conflict was used as a mediator between informal communication and project success, the impact was observed to be positive, and mediation was partial (H4b). In informal communication, people tend to know each other, and communication is enhanced. A role is played by task conflict in this regard. With the help of informal communication, people develop trust. So, they argue with each other about the execution or possibilities of execution of a certain tsk and, thus, find different ways to accomplish a certain task, and project success is facilitated [59].

Communication willingness and project success were mediated by task conflict positively and significantly. Mediation was partial in this case (H4c). When they have a will or intention to talk to each other and know each other, then hesitation is reduced and frankness increases, accomplishing a task becomes easier for them, and the project becomes successful $[68,69]$.

When process conflict was introduced as a mediator between formal communication and project success, the negative impact of formal communication was enhanced because of the negative impact of process conflict on the relation. Mediation was observed to be partial (H5a). A difference in opinion about the responsibility of certain tasks or authoritarian issues or assignment of duties is referred to as a process conflict. As discussed previously, formal communication does not remove barriers among team members but, at the same time, if process conflict arises then results are detrimental for project success [70]. 
When process conflict is introduced as a mediator between informal communication and project success, the impact is negative with partial mediation $(\mathrm{H} 5 \mathrm{~b})$. When process conflict is introduced as a mediator between communication willingness and project success, the impact is negative with partial mediation $(\mathrm{H} 5 \mathrm{c})$. The reason behind this type of conflict damages trust and collaboration among team members and they hesitate or do not bother to talk to each other, and project success suffers [31,70].

It is found that relationship conflict has a negative impact on all the direct relations, and mediation is observed to be partial. When relationship conflict was introduced as a mediator between formal communication and project success, the negative impact of formal communication increased due to the relationship conflict as it was also inducing a negative impact (H6a). When people have private or personal quarrels and differences, then they begin to disagree with each other in formal means of communication, and project success is halted [68].

When informal communication and project success were mediated by relationship conflict, the impact was found to be negative on this positive relation (H6b). This conflict is related to relations among people and, if emotions are hurt, then even informal communication causes conflicts among them. Similarly, the mediating effect of relationship conflict was observed to be negative on the relation of communication willingness and project success (H6c). It is because of the reason that disagreements due to personal differences make them hesitate to communicate freely, and information is not transferred timely, hence, project success is halted [70].

\section{Conclusions and Managerial Implications}

In developing countries, construction projects are increasing day by day. However, the construction industry is faced with the problems of miscommunication and conflict. Achieving project success is becoming increasingly difficult with every passing day. The main purpose of this study was to analyze the effect of communication types or dimensions on project success. It has been found that formal communication negatively affects the project success, whereas informal communication and communication willingness have a positive impact. The results of the direct relations of this study revealed and suggested that the project managers and owners of the companies must encourage healthy communication among team members. A communication mechanism must be developed at sites or site offices and must be followed by all teams under the supervision or leadership of the project manager. Official meetings, discussions, and emails are a form of communication, but since these mediums do not enable people to get to know each other, coordination in a task is difficult to achieve. The view of some researchers is that informal communication has a devastating nature on project success, but the empirical results suggested that informal communication enhances trust and coordination, which is also suggested by some researchers. Willingness to communicate must also be encouraged because people tend to know each other, and this is important for the development of trust and coordination, which is important to achieve project success.

When people or team members challenge someone's authority or refuse to do a task directed by a superior, then not only does the project success suffer, but conflict also arises and member(s) start to quarrel with each other, and the project progress is affected badly and, in some circumstances, the project temporarily stops its progress. Similarly, when team members have differences among themselves over personal issues or personal liking or disliking, then project success is not achieved. It can be concluded that task conflict must be encouraged by the project manager, whereas process and relationship conflict must be avoided to the maximum extent, and a strong conflict resolution mechanism is needed to make projects successful.

These findings can help policymakers, constructors, and marketers to provide proper training and services to improve communication skills of employees to reduce conflicts and achieve project success. This study can also help investors to assess the results of their newly launched projects and provides information on how training can bring change to 
the attitudes of employees. Furthermore, it explores the main factors involved in raising conflict through different types of communication.

\section{Limitations and Future Recommendations}

There are several limitations of this study. First, only professionals from Lahore city were approached. The responses of project managers were relatively lower than the other designated professionals. Respondents from consultants and clients were lesser in number. The model can be tested in other settings and can make a comparison between emerging and developed economies. The introduction of task, process and relationship conflict, as a mediating variable, resulted in partial mediation, indicating the need to introduce some other variables as a mediator in the model, such as contract types and trust among team members, etc.

Author Contributions: For this research articles six authors contributed. S.M. supervised the study and contributed in conceptualization and methodology. M.T. contributed in data collection, formal analysis and writing the original draft of paper. J.M.M. played its role in result validation and interpretation of data. M.N.M. provided software and contributed in data curation. J.M.P. helped in analysis and writing the manuscript. A.A. reviewed the final draft and did editing. All authors have read and agreed to the published version of the manuscript.

Funding: This research was supported by Instituto Politécnico de Lisboa.

Data Availability Statement: Not applicable.

Acknowledgments: We thank Instituto Politécnico de Lisboa for providing funding for this study.

Conflicts of Interest: The authors declare no conflict of interest.

\section{References}

1. Wawak, S.; Ljevo, Ž.; Vukomanović, M. Understanding the Key Quality Factors in Construction Projects-A Systematic Literature Review. Sustainability 2020, 12, 10376. [CrossRef]

2. Lopes, J.; Oliveira, R.; Abreu, M.I. The Sustainability of the Construction Industry in Sub-saharan Africa: Some New Evidence from Recent Data. Procedia Eng. 2017, 172, 657-664. [CrossRef]

3. Scarbrough, H.; Swan, J.; Laurent, S.; Bresnen, M.; Edelman, L.F.; Newell, S. Project-Based Learning and the Role of Learning Boundaries. Organ. Stud. 2004, 25, 1579-1600. [CrossRef]

4. Aslan, S.; Arditi, D.; Tantekin-Çelik, G. Factors That Affect the Level of Success of the Transaction between Home Buyers and Developers in Sell-Build Residential Projects. Buildings 2021, 11, 127. [CrossRef]

5. Acharya, N.K.; Lee, Y.D.; Im, H.M. Conflicting factors in construction projects: Korean perspective. Eng. Constr. Arch. Manag. 2006, 13, 543-566. [CrossRef]

6. Cheung, S.O.; Yiu, T.W.; Lam, M.C. Interweaving Trust and Communication with Project Performance. J. Constr. Eng. Manag. 2013, 139, 941-950. [CrossRef]

7. Wong, F.W.H.; Lam, P.T.I. Difficulties and Hindrances Facing End Users of Electronic Information Exchange Systems in Design and Construction. J. Manag. Eng. 2011, 27, 28-39. [CrossRef]

8. Nielsen, Y.; Erdogan, B. Level of visualization support for project communication in the Turkish construction industry: A quality function deployment approach. Can. J. Civ. Eng. 2007, 34, 19-36. [CrossRef]

9. Wong, A.S.H.; Tjosvold, D.W.; Wong, W.Y.L.; Liu, C.K. Cooperative and competitive conflict for quality supply partnerships between China and Hong Kong. Int. J. Phys. Distrib. Logist. Manag. 1999, 29, 7-21. [CrossRef]

10. Jelodar, M.B.; Yiu, T.W.; Wilkinson, S. Systematic Representation of Relationship Quality in Conflict and Dispute: For Construction Projects. Constr. Econ. Build. 2015, 15, 89-103. [CrossRef]

11. Atkinson, R. Project management: Cost, time and quality, two best guesses and a phenomenon, its time to accept other success criteria. Int. J. Proj. Manag. 1999, 17, 337-342. [CrossRef]

12. Bryde, D.J.; Robinson, L. Client versus contractor perspectives on project success criteria. Int. J. Proj. Manag. 2005, 23, 622-629. [CrossRef]

13. Lim, C.; Mohamed, M. Criteria of project success: An exploratory re-examination. Int. J. Proj. Manag. 1999, 17, 243-248. [CrossRef]

14. Liu, B.; Huo, T.; Meng, J.; Gong, J.; Shen, Q.; Sun, T. Identification of Key Contractor Characteristic Factors That Affect Project Success under Different Project Delivery Systems: Empirical Analysis Based on a Group of Data from China. J. Manag. Eng. 2016, 32, 05015003. [CrossRef]

15. Zhang, L.; Huo, X. The impact of interpersonal conflict on construction project performance. Int. J. Confl. Manag. 2015, 26, 479-498. [CrossRef] 
16. Tiron-Tudor, A.; Ioana-Maria, D. Sustainability Integration for Effective Project Management; IGI Global Publishing: Utrecht, The Netherlands, 2013; Chapter 7; pp. 106-127.

17. Dai, Y.; Bai, Y. Performance Improvement for Building Integrated Photovoltaics in Practice: A Review. Energies 2020, 14, 178. [CrossRef]

18. Sivius, A.J.G.; Schipper, R. Exploring the relationship between sustainability and project success-Conceptual model and expected relationships. Int. J. Inf. Syst. Proj. Manag. 2016, 4, 5-22. [CrossRef]

19. Mishra, P.; Dangayach, G.; Mittal, M. An Ethical approach towards sustainable project Success. Procedia Soc. Behav. Sci. 2011, 25, 338-344. [CrossRef]

20. Project Management Institue Coe of Ethics and Professional Conduct. Available online: https://www.pmi.org/about/ethics/code (accessed on 4 April 2021).

21. Axley, S.R. Managerial and Organizational Communication in Terms of the Conduit Metaphor. Acad. Manag. Rev. 1984, 9, 428. [CrossRef]

22. Chen, J.-H.; Su, M.-C.; Azzizi, V.-T.; Wang, T.-K.; Lin, W.-J. Smart Project Management: Interactive Platform Using Natural Language Processing Technology. Appl. Sci. 2021, 11, 1597. [CrossRef]

23. Love, P.E.; Irani, Z.; Li, H.; Cheng, E.W.; Tse, R.Y. An empirical analysis of the barriers to implementing e-commerce in small-medium sized construction contractors in the state of Victoria, Australia. Constr. Innov. 2001, 1, 31-41. [CrossRef]

24. Hosseini, M.R.R.; Zavadskas, E.K.; Xia, B.; Chileshe, N.; Mills, A. Communications in Hybrid Arrangements: Case of Australian Construction Project Teams. Eng. Econ. 2017, 28, 290-300. [CrossRef]

25. Badir, Y.F.; Büchel, B.; Tucci, C.L. A conceptual framework of the impact of NPD project team and leader empowerment on communication and performance: An alliance case context. Int. J. Proj. Manag. 2012, 30, 914-926. [CrossRef]

26. Fenn, P.; Lowe, D.; Speck, C. Conflict and dispute in construction. Constr. Manag. Econ. 1997, 15, 513-518. [CrossRef]

27. Wall, J.A.; Callister, R.R. Conflict and Its Management. J. Manag. 1995, 21, 515-558. [CrossRef]

28. Chandolia, E.; Anastasiou, S. Leadership and Conflict Management Style Are Associated with the Effectiveness of School Conflict Management in the Region of Epirus, NW Greece. Eur. J. Investig. Health Psychol. Educ. 2020, 10, 34. [CrossRef]

29. Bakker, A.B.; Albrecht, S.L.; Leiter, M.P. Work engagement: Further reflections on the state of play. Eur. J. Work. Organ. Psychol. 2011, 20, 74-88. [CrossRef]

30. Chua, R.Y.J. The Costs of Ambient Cultural Disharmony: Indirect Intercultural Conflicts in Social Environment Undermine Creativity. Acad. Manag. J. 2013, 56, 1545-1577. [CrossRef]

31. He, Y.; Ding, X.-H.; Yang, K. Unpacking the relationships between conflicts and team innovation. Manag. Decis. 2014, 52, 1533-1548. [CrossRef]

32. O'Neill, T.A.; Allen, N.J.; Hastings, S.E. Examining the "Pros" and "Cons" of TeamConflict: A Team-Level Meta-Analysis of Task, Relationship, and Process Conflict. Hum. Perform. 2013, 26, 236-260. [CrossRef]

33. Alarcón, L.F.; Ashley, D.B. Modeling Project Performance for Decision Making. J. Constr. Eng. Manag. 1996, 122, $265-273$. [CrossRef]

34. Dvir, D.; Lechler, T. Plans are nothing, changing plans is everything: The impact of changes on project success. Res. Policy 2004, 33, 1-15. [CrossRef]

35. Davis, K. Different stakeholder groups and their perceptions of project success. Int. J. Proj. Manag. 2014, 32, 189-201. [CrossRef]

36. Bahmani, H.; Zhang, W. Application of System Thinking and Factors Interrelationship Analysis to Identify Primary Success Factors of Post-Natural Disaster Recovery Projects. Sustainability 2021, 13, 3392. [CrossRef]

37. Williams, T. Identifying Success Factors in Construction Projects: A Case Study. Proj. Manag. J. 2016, 47, 97-112. [CrossRef]

38. Sudhakar, G.P. A model of critical success factors for software projects. J. Enterp. Inf. Manag. 2012, 25, 537-558. [CrossRef]

39. Salman, A.; Jaafar, M.; Malik, S.; Mohammad, D.; Muhammad, S.A. An Empirical Investigation of the Impact of the Communication and Employee Motivation on the Project Success Using Agile Framework and Its Effect on the Software Development Business. Bus. Perspect. Res. 2021, 9, 46-61. [CrossRef]

40. Kerzner, H. Strategic Planning for a Project Office. Proj. Manag. J. 2003, 34, 13-25. [CrossRef]

41. Ofori, D.F. Project Management Practices and Critical Success Factors-A Developing Country Perspective. Int. J. Bus. Manag. 2013, 8, 14. [CrossRef]

42. Shohet, I.M.; Laufer, A. What does the construction foreman do? Constr. Manag. Econ. 1991, 9, 565-576. [CrossRef]

43. Ding, Z.; Ng, F.; Cai, Q. Personal constructs affecting interpersonal trust and willingness to share knowledge between architects in project design teams. Constr. Manag. Econ. 2007, 25, 937-950. [CrossRef]

44. Butt, A.; Naaranoja, M.; Savolainen, J. Project change stakeholder communication. Int. J. Proj. Manag. 2016, 34, 1579-1595. [CrossRef]

45. Shohet, I.M.; Frydman, S. Communication Patterns in Construction at Construction Manager Level. J. Constr. Eng. Manag. 2003, 129, 570-577. [CrossRef]

46. Senaratne, S.; Ruwanpura, M. Communication in construction: A management perspective through case studies in Sri Lanka. Arch. Eng. Des. Manag. 2015, 12, 1-16. [CrossRef]

47. Christensen, S.; Mc Namara, J.; O'Shea, K. Legal and contracting issues in electronic project administration in the construction industry. Struct. Surv. 2007, 25, 191-203. [CrossRef] 
48. Hewage, K.N.; Ruwanpura, J.Y. A novel solution for construction on-site communication-The information booth. Can. J. Civ. Eng. 2009, 36, 659-671. [CrossRef]

49. Farooqui, R.; Ahmed, S.; Lodi, S. Assessment of Pakistani Construction Industry-Current Performance and the Way Forward. J. Adv. Perform. Inf. Value 2008, 1, 51. [CrossRef]

50. Awakul, P.; Ogunlana, S.O. The effect of attitudinal differences on interface conflicts in large scale construction projects: A case study. Constr. Manag. Econ. 2002, 20, 365-377. [CrossRef]

51. Adnan, H.; Shamsuddin, S.M.; Supardi, A.; Ahmad, N. Conflict Prevention in Partnering Projects. Procedia Soc. Behav. Sci. 2012, 35, 772-781. [CrossRef]

52. Mahato, B.K.; Ogunlana, S.O. Conflict dynamics in a dam construction project: A case study. Built Environ. Proj. Asset Manag. 2011, 1, 176-194. [CrossRef]

53. Somech, A.; Desivilya, H.S.; Lidogoster, H. Team conflict management and team effectiveness: The effects of task interde-pendence and team identification. Int. J. Ind. Occup. Organ. Psychol. Behav. 2009, 30, 359-378. [CrossRef]

54. Menguc, B.; Auh, S. Conflict, leadership, and market orientation. Int. J. Res. Mark. 2008, 25, 34-45. [CrossRef]

55. Wu, G.; Zhao, X.; Zuo, J.; Zillante, G. Effects of contractual flexibility on conflict and project success in megaprojects. Int. J. Confl. Manag. 2018, 29, 253-278. [CrossRef]

56. Hu, N.; Chen, Z.; Gu, J.; Huang, S.; Liu, H. Conflict and creativity in inter-organizational teams. Int. J. Confl. Manag. 2017, 28, 74-102. [CrossRef]

57. Wu, G.; Zhao, X.; Zuo, J. Relationship between Project's Added Value and the Trust-Conflict Interaction among Project Teams. J. Manag. Eng. 2017, 33, 04017011. [CrossRef]

58. Simons, T.L.; Peterson, R.S. Task conflict and relationship conflict in top management teams: The pivotal role of intragroup trust. J. Appl. Psychol. 2000, 85, 102-111. [CrossRef] [PubMed]

59. Wu, G.; Liu, C.; Zhao, X.; Zuo, J. Investigating the relationship between communication-conflict interaction and project success among construction project teams. Int. J. Proj. Manag. 2017, 35, 1466-1482. [CrossRef]

60. Beleiu, I.; Crisan, E.; Nistor, R. Main Factors Influencing Project Success. Int. Manag. Res. 2015, 11, 59-72. Available online: https:/ /EconPapers.repec.org/RePEc:osi:journl:v:11:y:2015:p:59-72 (accessed on 14 February 2021).

61. Rana, I.A.; Bhatti, S.S. Lahore, Pakistan-Urbanization challenges and opportunities. Cities 2018, 72, 348-355. [CrossRef]

62. Bartlett, J.M.; Kotrlik, J.W.; Higgins, C.C. Organizational Research: Determining Appropriate Sample Size in Survey Re-search. Inf. Tech. Learn. Perform. J. 2001, 19, 43-50.

63. Jr, J.F.H.; Sarstedt, M.; Hopkins, L.; Kuppelwieser, V.G. Partial least squares structural equation modeling (PLS-SEM): An emerging tool in business research. Eur. Bus. Rev. 2014, 26, 106-121. [CrossRef]

64. Afthanorhan, A.; Ahmad, S. Afthanorhan, Asyraf \& Ahmad, Sabri. (2014). the Importance-Performance Matrix Analysis in Partial Least Square Structural Equation Modeling (pls-sem) with smartpls 2.0 MInt. J. Math. Res. 2014, 3, 1-14.

65. Vaske, J.J.; Beaman, J.; Sponarski, C.C. Rethinking Internal Consistency in Cronbach's Alpha. Leis. Sci. 2017, 39, 163-173. [CrossRef]

66. Ab Hamid, M.R.; Sami, W.; Sidek, M.H.M. Discriminant Validity Assessment: Use of Fornell \& Larcker criterion versus HTMT Criterion. J. Phys. Conf. Ser. 2017, 890, 012163. [CrossRef]

67. Hair, J.F.; Ringle, C.M.; Sarstedt, M. PLS-SEM: Indeed a Silver Bullet. J. Mark. Theory Pract. 2011, 19, 139-152. [CrossRef]

68. Martínez-Moreno, E.; González-Navarro, P.; Zornoza, A.; Ripoll, P. Relationship, task and process conflicts on team performance: The moderating role of communication media. Int. J. Confl. Manag. 2009, 20, 251-268. [CrossRef]

69. Jehn, K.A.; Mannix, E.A. The dynamic Nature of Conflict: A Longitudinal Study of Intragroup Conflict and Group Performance. Acad. Manag. J. 2001, 44, 238-251. Available online: https:/ /www.jstor.org/stable/3069453 (accessed on 15 March 2021).

70. $\mathrm{Wu}, \mathrm{G}$. The relationship between project team dynamic feature, conflict dimension and project success-An empirical research from Shanghai, China. Pak. J. Stat. 2013, 29, 935-952. 